\title{
Gambaran Tingkat Stres pada Mahasiswa Fakultas Kedokteran Universitas Riau Tahun Pertama
}

\author{
Rony Wahyudi ${ }^{1}$, Eka Bebasari², Elda Nazriati ${ }^{2}$
}

\begin{abstract}
The prevalence of stress on medical students is very high, especially on first grade medical students. The problem to adapt to new environment is the most common cause of stress occuring on first grade medical students. Stress can become negative effect to person. The aim of this study was to understand the stress levels on first grade medical students of Faculty of Medicine, University of Riau. This study used descriptive design with cross-sectional approach. Samples in this study were 166, using total sampling technique. Data was accumulated by using Medical Student Stressor Questionnaire (MSSQ) that had been modified for stress levels. The results showed that $57.23 \%$ had moderate stress levels with stressors related academic and stressors related teaching-learning relationship as the highest stressors.
\end{abstract}

Keyword: stress levels, exercise habits, first grade medical students, MSSQ

Stres merupakan suatu fenomena yang sering terjadi dalam kehidupan sehari-hari yang tidak dapat dihindari dan akan dialami oleh setiap orang. Stres normal dialami setiap individu dan menjadi bagian yang tak terpisahkan dalam kehidupan. Stres membuat seseorang yang mengalaminya berpikir dan berusaha keras dalam menyelesaikan suatu permasalahan atau tantangan dalam hidup sebagai bentuk respon adaptasi untuk tetap bertahan. ${ }^{1}$

Berbagai penelitian menunjukkan bahwa mahasiswa kedokteran memiliki prevalensi kejadian stres yang cukup tinggi, terutama bagi mahasiswa tahun pertama. Permasalahan adaptasi terhadap sistem pembelajaran di perkuliahan menjadi penyebab stres terbesar bagi mahasiswa tahun pertama. ${ }^{2}$ Hal ini dibuktikan oleh Abdulghani di Arab Saudi, diketahui bahwa prevalensi stres pada mahasiswa tahun pertamasebanyak 78,7\%, merupakan yang tertinggi dibandingkan dengan tahun tahun-tahun di atasnya. ${ }^{3}$

\footnotetext{
1 Penulis untuk korespondensi : Fakuktas Kedokteran Universitas Riau

2 Bagian Fisiologi Fakultas Kedokteran Universitas Riau
}

Pada penelitian ini, mahasiwa tahun pertama Fakultas Kedokteran Universitas Riau terdiri dari 166 mahasiswa yang berasal dari berbagai daerah di dalam maupun di luar Provinsi Riau. Perbedaan kultur, tempat tinggal yang baru bagi mahasiswa yang datang dari luar Pekanbaru, dan ekonomi keluarga juga menjadi tuntutan tersendiri bagi mahasiswa-mahasiswa tersebut. Hal ini menjadi stresor bagi mahasiswa dan dapat menimbulkan stres yang akan berakibat buruk jika tidak diatasi dengan baik.

Stres yang dihadapi mahasiwa dapat berdampak pada aspek psikologis. Dampak tersebut dapat berupa dampak positif dan dampak negatif. Dampak positif dari stres tersebut berupa peningkatan kreativitas dan memicu pengembangan diri, selama stres yang dialami masih dalam batas kapasitas individu tersebut. Dampak negatif dari stres dapat berupa penurunan konsentrasi dan pemusatan perhatian selama kuliah, penurunan minat, demotivasi diri bahkan dapat menimbulkan perilaku kurang baik seperti sengaja terlambat datang ketika kuliah, minum alkohol, merokok dan sebagainya. ${ }^{2,3}$ Oleh karena itu, peneliti tertarik untuk meneliti gambaran tingkat stres pada mahasiswa tahun pertama Fakultas Kedokteran Universitas Riau 


\section{METODE PENELITIAN}

Penelitian ini merupakan penelitian deskriptif. Populasi penelitian ini adalah seluruh mahasiswa Fakultas Kedokteran Universitas Riau tahun pertama, yang berjumlah 166 orang. Penelitian ini menggunakan metode total sampling, yaitu mengambil seluruh data dari populasi yang memenuhi kriteria inklusi dan tidak memenuhi kriteria eksklusi. Kriteria inklusi pada penelitian ini adalah mahasiswa Fakultas Kedokteran Universitas Riau tahun pertama yang bersedia mengikuti penelitian dan mengisi informed concent dan kriteria ekslusi, yaitu mahasiswa yang menggunakan obatobatan antiansietas dan atau obat-obatan antidepresan, mahasiswa yang tercatat sebagai atlet, mahasiswa yang memiliki penyakit kronis yang mengganggu aktivitas olahraganya, seperti penyakit jantung, dan Penyakit Paru Obstruktif Kronis (PPOK).

Instrumen pada penelitian ini menggunakan Medical Student Stressor Questionnaire (MSSQ) yang telah dimodifikasi untuk tingkat stress. Data dikumpulkan melalui kuesioner yang dibagikan kepada para responden. Sebelumnya responden diberikan penjelasan tentang cara pengisian, tujuan dari kuesioner dan disertai petunjuk pengisian kuesioner. Penelitian ini telah dinyatakan lulus kaji etik oleh Unit Etik Fakultas Kedokteran Universitas Riau berdasarkan Surat Keterangan Lolos Kaji Etik nomor 130/UN19.1.28/UEPKK/pertama.

\section{HASIL PENELITIAN}

\section{Karakteristik umum subjek penelitian}

Subjek penelitian ini adalah mahasiswa Fakultas Kedokteran Universitas Riau tahun pertama yang berjumlah 166 orang. Berdasarkan data yang diperoleh, ditetapkan bahwa seluruh mahasiswa Fakultas Kedokteran Universitas Riau tahun pertama memenuhi kriteria inklusi. Sampel terdiri dari 40 laki-laki dan 126 perempuan. Sebaran usia responden berkisar 16 sampai 20 tahun dengan jumlah masing-masing, usia 16 tahun sebanyak 2 orang, usia 17 tahun sebanyak 13 orang, usia 18 tahun sebanyak 124 orang, usia 19 tahun sebanyak 25 orang, dan usia 20 tahun sebanyak 2 orang. Sebaran data berdasarkan tempat tinggal didapatkan 82 responden tinggal sendiri dan 84 responden tinggal bersama orang tua.

\section{Gambaran Tingkat Stres pada Mahasiswa Fakultas Kedokteran Universitas Riau Tahun pertama}

Berdasarkan data yang diperoleh dengan menggunakan medical student stress questionnaire (MSSQ) didapatkan gambaran tingkat stres mahasiswa Fakultas Kedokteran Universitas Riau tahun pertama seperti terlihat pada tabel 1 .

Tabel 1. Distribusi tingkat stres responden

\begin{tabular}{lll}
\hline Kategori & Frekuensi & Persentase (\%) \\
\hline Ringan & 38 & 22,89 \\
Sedang & 95 & 57,23 \\
Berat & 29 & 17,47 \\
Sangat Berat & 4 & 2,41 \\
\hline Total & 166 & 100 \\
\hline
\end{tabular}

Tabel 1 di atas menunjukkan bahwa frekuensi tingkat stres pada mahasiswa Fakultas Kedokteran Universitas Riau tahun pertama terbanyak adalah stres sedang yaitu 95 responden $(57,23 \%)$, sedangkan frekuensi tingkat stres paling sedikit yaitu stres sangat berat sebanyak 4 responden (2,41\%).
Stres yang dialami oleh responden dapat terjadi karena adanya stresor. Terdapat beberapa jenis stresor yang mendasari terjadinya stres pada mahasiswa. Tingkat stres terkait akademis pada mahasiswa Fakultas Kedokteran Universitas Riau tahun pertama dapat dilihat pada tabel 2 . 
Tabel 2. Distribusi tingkat stres terkait akademis

\begin{tabular}{lll}
\hline Kategori & Frekuensi & Persentase $(\%)$ \\
\hline Ringan & 33 & 19,88 \\
Sedang & 94 & 56,63 \\
Berat & 38 & 22,89 \\
Sangat berat & 1 & 0,60 \\
Total & 166 & 100 \\
\hline
\end{tabular}

Tabel 2 menunjukkan bahwa tingkat stres terkait akademik yang paling banyak dialami oleh mahasiswa Fakultas Kedokteran Universitas Riau tahun pertama adalah tingkat stres sedang yang berjumlah 94 responden (56,63\%), sedangkan tingkat stres terkait akademik yang paling sedikit adalah tingkat stres sangat berat yaitu 1 responden (0,60\%).

Tingkat stres terkait hubungan intrapersonal dan interpersonal pada mahasiswa Fakultas Kedokteran Universitas Riau tahun pertama dapat dilihat pada tabel 3

Tabel 3. Distribusi tingkat stres terkait hubungan intrapersonal dan interpersonal

\begin{tabular}{lll}
\hline Kategori & Frekuensi & Persentase $(\%)$ \\
\hline Ringan & 65 & 39,16 \\
Sedang & 58 & 34,94 \\
Berat & 31 & 18,67 \\
Sangat berat & 12 & 7,23 \\
Total & 166 & 100 \\
\hline
\end{tabular}

Tabel 3 menunjukkan bahwa tingkat stres terkait hubungan intrapersonal dan interpersonal yang paling banyak dialami oleh mahasiswa Fakultas Kedokteran Universitas Riau tahun pertama adalah tingkat stres ringan sebanyak 65 responden (39,16\%), sedangkan tingkat stres terkait hubungan intrapersonal dan interpersonal yang paling sedikit adalah tingkat stres sangat berat sebanyak 12 responden $(7,23 \%)$.

Tingkat stres terkait hubungan belajar pada mahasiswa Fakultas Kedokteran Universitas Riau tahun pertama dapat dilihat pada tabel 4 .

Tabel 4. Distribusi tingkat stres terkait hubungan belajar

\begin{tabular}{lll}
\hline Kategori & Frekuensi & Persentase (\%) \\
\hline Ringan & 33 & 19,88 \\
Sedang & 82 & 49,40 \\
Berat & 44 & 26,50 \\
Sangat berat & 7 & 4,22 \\
Total & 166 & 100 \\
\hline
\end{tabular}

Tabel 4 menunjukkan bahwa tingkat stres terkait hubungan belajar-mengajar yang paling banyak dialami oleh mahasiswa Fakultas Kedokteran Universitas Riau tahun pertama adalah tingkat stres sedang yang berjumlah 82 responden (49,40\%), sedangkan tingkat stres terkait hubungan belajar yang paling sedikit adalah tingkat stres sangat berat yaitu 7 responden $(4,22 \%)$. 
Tingkat stres terkait hubungan sosial pada mahasiswa Fakultas Kedokteran Universitas Riau tahun pertama dapat dilihat pada tabel 5 .

Tabel 5. Distribusi tingkat stres terkait hubungan sosial

\begin{tabular}{lll}
\hline Kategori & Frekuensi & Persentase $(\%)$ \\
\hline Ringan & 64 & 38,56 \\
Sedang & 71 & 42,77 \\
Berat & 26 & 15,66 \\
Sangat berat & 5 & 3,01 \\
Total & 166 & 100 \\
\hline
\end{tabular}

Tabel 5 di atas menunjukkan bahwa tingkat stres terkait hubungan sosial yang paling banyak dialami oleh mahasiswa Fakultas Kedokteran Universitas Riau tahun pertama adalah tingkat stres sedang sebanyak 71 responden (42,77\%), sedangkan tingkat stres terkait hubungan sosial yang paling sedikit adalah tingkat stres sangat berat yaitu 5 responden (3,01\%).

Tingkat stres terkait keinginan dan pengendalian pada mahasiswa Fakultas Kedokteran Universitas Riau tahun pertama dapat dilihat pada tabel 6 .

Tabel 6. Distribusi tingkat stres terkait keinginan dan pengendalian

\begin{tabular}{lll}
\hline Kategori & Frekuensi & Persentase (\%) \\
\hline Ringan & 91 & 54,82 \\
Sedang & 44 & 26,51 \\
Berat & 18 & 10,84 \\
Sangat berat & 13 & 7,83 \\
Total & 166 & 100 \\
\hline
\end{tabular}

Tabel 6 di atas menunjukkan bahwa tingkat stres terkait keinginan dan pengendalian yang paling banyak dialami oleh mahasiswa Fakultas Kedokteran Universitas Riau tahun pertama adalah tingkat stres ringan sebanyak 91 responden (54,82\%), sedangkan tingkat stres terkait keinginan dan pengendalian yang paling sedikit adalah tingkat stres sangat berat sebanyak 13 responden $(7,83 \%)$.

Tingkat stres terkait aktivitas kelompok pada mahasiswa Fakultas Kedokteran Universitas Riau tahun pertama dapat dilihat pada tabel 7 .

Tabel 7. Distribusi tingkat stres terkait aktivitas kelompok

\begin{tabular}{lll}
\hline Kategori & Frekuensi & Persentase $(\%)$ \\
\hline Ringan & 108 & 65,06 \\
Sedang & 38 & 22,89 \\
Berat & 17 & 10,24 \\
Sangat berat & 3 & 1,81 \\
Total & 166 & 100 \\
\hline
\end{tabular}

Tabel 7 menunjukkan bahwa tingkat stres terkait aktivitas kelompok yang paling banyak dialami oleh mahasiswa Fakultas Kedokteran Universitas Riau tahun pertama adalah tingkat stres ringan yang berjumlah 108 responden (65,06\%), sedangkan tingkat stres terkait akademik yang paling sedikit adalah tingkat stres sangat berat yaitu 3 responden $(1,81 \%)$. 


\section{PEMBAHASAN}

\section{Gambaran Tingkat Stres pada Mahasiswa Fakultas Kedokteran Universitas Riau Tahun pertama}

Hasil penelitian ini menunjukkan gambaran tingkat stres mahasiswa Fakultas Kedokteran Universitas Riau tahun pertama yang terbanyak yaitu stres sedang dengan 95 responden (57,23\%), sedangkan yang paling sedikit adalah stres sangat berat yaitu 4 responden (41\%). Hal ini sesuai dengan penelitian Suganda (pertama) yang mengatakan bahwa mahasiwa tahun pertama di Fakultas Kedokteran Universitas Sumatera Utara memiliki tingkat stres terbanyak pada tingkat stres sedang yaitu $86,5 \%{ }^{4}$

Respon terhadap stres yang diberikan setiap individu berbeda-beda. Hal ini disebabkan oleh berbagai faktor seperti faktor kepribadian, karakteristik stresor dan kemampuan adaptasi individu terhadap stres atau strategi koping terhadap stres yang dihadapi. Faktor kepribadian sangat berpengaruh terhadap bagaimana seseorang mengolah stresor sehingga menimbulkan dampak stres yang berbeda. ${ }^{5}$ Kemampuan adaptasi dan strategi koping mahasiswa juga berperan dalam respon tubuh terhadap stres, seseorang yang kurang baik dalam hal adaptasi atau mengkoping stres maka stres tidak dapat teratasi secara keseluruhan sehingga menimbulkan dampak negatif dari stres. ${ }^{6}$ Dampak negatif dari stres terhadap mahasiswa dapat berupa penurunan konsentrasi dan pemusatan perhatian selama kuliah, penurunan minat, demotivasi diri bahkan dapat menimbulkan perilaku kurang baik seperti sengaja terlambat datang ketika kuliah, minum alkohol, merokok dan sebagainya. ${ }^{2,3}$

\section{Gambaran Tingkat Stres berdasarkan stressor pada Mahasiswa Fakultas Kedokteran Universitas Riau tahun pertama}

Tingkat stres terkait akademik pada mahasiswa Fakultas Kedokteran Universitas Riau tahun pertama sebagian besar mengalami tingkat stres sedang yang berjumlah 94 responden (56,63\%). Berdasarkan hasil jawaban dari kuesioner, stres akademik dapat terjadi karena tekanan terhadap ujian, tugas-tugas kuliah yang harus dikerjakan dan waktu perkuliahan yang padat. Hasil penelitian ini sesuai dengan penelitian Sharif et al (2007) di Iraq pada mahasiswa kedokteran, mengatakan bahwa penyebab stres akademik tersering pada mahasiswa kedokteran yaitu tuntutan terhadap ujian serta waktu belajar yang sangat padat. ${ }^{5}$

Tingkat stres terkait hubungan intrapersonal dan interpersonal pada mahasiswa Fakultas Kedokteran Universitas Riau tahun pertama sebagian besar adalah tingkat stres ringan sebanyak 65 responden (39,16\%). Berdasarkan hasil jawaban kuesioner, stres ini disebabkan karena adanya konflik dalam diri individu itu sendiri, konflik dengan sesama mahasiswa, staf pengajar, serta karyawan di kampus.

Interpretasi penelitian ini menunjukkan bahwa stres terkait hubungan intrapersonal dan interpersonal responden terbanyak pada tingkat stres ringan. Hal ini disebabkan faktor kepribadian mahasiswa yang berbeda-beda. Perbedaan kepribadian berperan penting terhadap hubungan baik terhadap diri sendiri maupun dengan orang lain, contohnya individu yang memiliki tipe kepribadian ekstrovert lebih mudah bergaul dan berkomunikasi dengan orang lain, sedangkan tipe kepribadian introvert lebih berorientasi pada dirinya sendiri seperti pikiran, suasana hati dan reaksi-reaksi yang terjadi dalam dirinya. ${ }^{7}$ Menurut penelitian Yusof et $a l$, hubungan interpersonal dan intrapersonal merupakan salah satu stresor yang dapat mempengaruhi tingkat stres bagi mahasiswa kedokteran. $^{8}$

Tingkat stres terkait hubungan belajarmengajar pada mahasiswa Fakultas Kedokteran Universitas Riau tahun pertama yang paling banyak adalah tingkat stres sedang yang berjumlah 82 responden $(49,40 \%)$. Berdasarkan jawaban kuesioner, stres ini terjadi karena banyaknya materi pelajaran yang harus dipelajari,kurangnya feedback yang diberikan dosen, kualitas dosen yang mengajar, serta banyaknya tugas yang diberikan dosen. ${ }^{9}$ Sesuai dengan penelitian Al-Dabal et al (2010) di Arab Saudi yang mengatakan bahwa metode mengajar dan lingkungan belajar merupakan salah satu penyebab stres bagi mahasiswa baik kedokteran maupun non-kedokteran. ${ }^{10}$

Tingkat stres terkait hubungan sosial pada mahasiswa Fakultas Kedokteran Universitas Riau tahun pertama yang terbanyak adalah adalah tingkat 
stres sedang sebanyak 71 responden (42.77\%). Berdasarkan hasil jawaban kuesioner, stres terkait hubungan sosial didapat karena adanya masalah dalam hal interaksi, baik dengan teman, saudara, maupun tetangga. Hal ini sesuai dengan penelitian Yusof (2011) di Malaysia yang mengatakan bahwa masalah interaksi sosial dapat menimbulkan stres bagi mahasiwa kedokteran. ${ }^{11}$ Penelitian Al-Dabal et al (2010) di Arab Saudi bahkan mengatakan bahwa masalah tertinggi pada mahasiswa kedokteran adalah masalah sosial. ${ }^{10}$

Tingkat stres terkait keinginan dan pengendalian pada mahasiswa Fakultas Kedokteran Universitas Riau tahun pertama yang terbanyak adalah tingkat stres ringan sebanyak 91 responden (54,82\%). Hasil jawaban kuesioner mengatakan bahwa stres terkait keinginan dan pengendalian ini dapat terjadi karena adanya tuntutan baik dari orang tua maupun dari orang lain kepada mahasiswa yang bertentangan dengan keinginan mahasiswa. Penelitian Yusof et al (2010) di Malaysia mengatakan bahwa dorongan dari keluarga terhadap mahasiswa dalam memilih suatu pilihan sehingga mahasiswa tidak memilih sesuai dengan keinginannya, hal ini dapat menimbulkan stres bagi mahasiswa tersebut. ${ }^{8}$

Pada penelitian ini, interpretasi stres terkait keinginan dan pengendalian didapatkan tingkat stres responden terbanyak yaitu tingkat stres ringan. Hal ini berarti tidak terdapat masalah yang berarti pada responden dalam hal tuntutan orang tua ataupun orang lain terhadap dirinya. Sesuai dengan penelitian Zaid et al (2007) yang mengatakan sebagian besar mahasiswa menyimpan permasalahannya sendiri tanpa menyampaikan permasalahannya kepada orang tua ataupun teman. ${ }^{12}$ Hal ini menunjukkan bahwa mahasiswa dapat mengkoping masalah terkait keinginan dan pengendalian sehingga stres dapat diatasi. ${ }^{6}$

Tingkat stres terkait aktivitas kelompok pada mahasiswa Fakultas Kedokteran Universitas Riau tahun pertama yang terbanyak adalah tingkat stres ringan yang berjumlah 108 responden (65,06\%). Berdasarkan hasil jawaban kuesioner, stres terkait aktivitas kelompok dapat terjadi karena adanya tuntutan dari teman sekelompok agar lebih baik, harus memiliki kemampuan yang lebih dan selalu ikut berpartisipasi aktif dalam kelompok tersebut.
Dari hasil penelitian ini stres terkait aktivitas kelompok terbanyak adalah tingkat stres ringan. Hal ini berarti bahwa aktivitas kelompok yang diikuti responden tidak menjadi masalah yang dapat menimbulkan stres. Hasil penelitian ini tidak sesuai dengan penelitian Shaikh et al (2004) yang mengatakan bahwa kesulitan berkomunikasi dengan teman kelompok dapat menyebabkan stres. ${ }^{13}$ Perbedaan hasil ini terjadi karena adanya perbedaan kemampuan dari individu untuk beradaptasi dengan lingkungan. Proses adaptasi terhadap stres akan memberikan pertahanan diri terhadap stresor sehingga tidak menimbulkan stres yang berkepanjangan. Peneliti tidak mendapatkan penelitian yang mengatakan bahwa aktivitas kelompok tidak berpengaruh terhadap terjadinya stres.

\section{SIMPULAN DAN SARAN}

Simpulan

1. Tingkat stres pada mahasiswa Fakultas Kedokteran Universitas Riau tahun pertama yang terbanyak adalah tingkat stres sedang sebanyak $57,23 \%$.

2. Tingkat stres terkait akademik yang terbanyak adalah tingkat stres sedang. Tingkat stres terkait hubungan intrapersonal dan interpersonal yang terbanyak adalah tingkat stres ringan. Tingkat stres terkait hubungan belajar-mengajar yang terbanyak adalah tingkat stres sedang. Tingkat stres terkait hubungan sosial yang terbanyak adalah tingkat stres sedang. Tingkat stres terkait keinginan dan pengendalian pada mahasiswa Fakultas Kedokteran Universitas Riau tahun pertama yang terbanyak adalah tingkat stres ringan. Tingkat stres terkait aktivitas kelompok pada mahasiswa Fakultas Kedokteran Universitas Riau tahun pertama yang terbanyak adalah tingkat stres ringan.

Saran

1. Mahasiswa Fakultas Kedokteran Universitas Riau diharapkan dapat memanajemen stresor yang dihadapi sehingga terhindar dari stres yang merugikan yang dapat menimbulkan penyakit psikiatri seperti depresi. 
2. Diharapkan agar pihak fakultas dapat mengoptimalkan unit bimbingan konseling sebagai tempat bimbingan bagi mahasiswa Fakultas Kedokteran Universitas Riau sehingga dapat mengurangi stress yang dialami mahasiswa

\section{UCAPAN TERIMA KASIH}

Penulis mengucapkan terima kasih kepada semua pihak yang telah berpartisipasi dalam menyelesaikan penelitian ini.

\section{DAFTAR PUSTAKA}

1. Purwati S. Tingkat stres akademik pada mahasiswa reguler angkatan 2010 Fakultas Ilmu Keperawatan Universitas Indonesia [Skripsi]. Depok: Fakultas Ilmu Keperawatan Universitas Indonesia; 2012.

2. Moffat KJ, McConnachiel A, Ross S, Morrison JM. First year medical student stress and coping in a problem-based learning medical curriculum. Medical Education. 2004; (38): 482-91.

3. Abdulghani HM. Stress and depression among medical students: a cross sectional study at Medical College in Saudi Arabia. Pakistan Journal Medical Science. 2008; (24): 12-7.

4. Suganda. Tingkat stres pada mahasiswa tahun pertama Fakultas Kedokteran Universitas Sumatera Utara tahun 2013. [Skripsi]. Medan: Fakultas Kedokteran Universitas Sumatera Utara; pertama.

5. Sharif S, Kamil EA, Mansour A. Stres and coping strategies among medical students in Basrah. Medical Journal of Basrah University. 2007: (25); 28-32.
6. Rasmun. Stres, koping dan adaptasi. Jakarta: SagungSeto; 2004.

7. Feist J, Feist GJ. Teorikepribadian. Jakarta: SalembaHumanika; 2010

8. Yusof MS, Rahim AF, Yaacob MJ. The development and validity of the medical student stressor questionnaire. ASEAN Jurnal of Psychiatry. 2010: (11); 1-12.

9. Yusof MS, Rahim AF. The medical student stressor questionnaire (MSSQ) manual. Kelantan: KKMED; 2010.

10.Al-Dabal BK, Koura MR, Rasheed P, AlSowielem L, Makki SM. A comparative study of perceived stress among female medical and non-medical university students in Dammam, Saudi Arabia. SQU Medical Journal. 2010; (10): 231-40.

11. Yusof MS. A confirmatory factor analysis study on the medical student stress questionnaire among Malaysian Medical Students. Education in Medicine Journal. 2011; 3(1): 44-53.

12.Zaid ZA, Chan SC, Ho JJ. Emotional disorders among medical student in a Malaysian private medical school. Singapore Medical Journal. 2007; 48(10): 895-9.

13.Shaikh B, Kahloon A, Kazmi M, Khalid H, Nawaz K, Khan S, et al. Students, stress and coping strategies: a case of Pakistani medical school. Education for Health. 2004; 17(3): 34653. 